\title{
Terpene accumulation in muscle and fatty tissues of calves supplemented with essential oils
}

\author{
E. Serrano ${ }^{1}$, A. Cornu ${ }^{1,2,4}$, N. Kondjoyan ${ }^{2}$, G. Figueredo ${ }^{3}$, J. Agabriel ${ }^{1}$ \\ and D. Micol ${ }^{1}$
}

${ }^{1}$ Unité de Recherches sur les Herbivores, INRA

Theix, F63122 Saint-Genès Champanelle, France

${ }^{2}$ Unité Qualité des Produits Animaux, INRA

Theix, F63122 Saint-Genès Champanelle, France

${ }^{3}$ Laboratoire de Chimie des Huiles Essentielles, Université Blaise Pascal

Les Cézeaux, F63177 Aubière, France

(Received 4 May 2006; revised version 22 January 2007; accepted 2 May 2007)

\begin{abstract}
Plant secondary metabolites such as terpenes, deposited in the fat of pasture-fed animals have been proposed as biomarkers in these animals. In this study, the accumulation of a variety of terpenes in muscle and adipose tissues was investigated in young bovines. Two calves were fed with artificial milk and two calves were administered the same artificial milk with a mixture of essential oils. Terpenes were analysed by gas chromatography-mass spectrometry in rectus abdominis intramuscular lipid, subcutaneous, intermuscular, perirenal and peritoneal adipose tissues. The enrichments obtained were weak. Terpenes appeared to preferably accumulate in perirenal and peritoneal fat. Sesquiterpenes were retained more than monoterpenes or their oxygenated derivatives in the tissues of the calves receiving essential oils. Tissue enrichment in the calves that had not ingested the essential oil was observed for a few terpenes, suggesting that lung absorption may also be an effective way of penetration.
\end{abstract}

KEY WORDS: calves, meat, biomarkers, grass feeding, terpenes,oils

\section{INTRODUCTION}

There is increasing consumer interest in animal products from "green" production systems. Since consumers often associate grass feeding with this category of

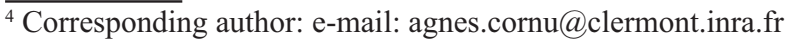


animal products, efforts have been made in recent years to enable direct tracing of grass feeding in herbivore products. Plant secondary metabolites such as terpenes have been proposed as biomarkers of pasture feeding in animal products (Martin et al., 2005; Prache et al., 2005). Terpenes are found in high amounts and wide molecular diversity in certain Apiaceae, Lamiaceae and Asteraceae found in permanent grasslands. In contrast, Poaceae, which are found in cultivated grasslands, only contain a few of the common terpenes, and in low amounts. A significant research effort has been directed towards tracing the cow's diet using terpene profiles in milk (Viallon et al., 2000; Fernandez et al., 2003) and in cheese (Favaro et al., 2005). Although terpenes have long been investigated in meat flavour studies (Larick et al., 1987; Young et al., 1997) examples of diet discrimination using terpene profiles are scarce (Cornu et al., 2001a; Priolo et al., 2004).

Several authors have suggested that, in general, terpene accumulation in tissues is very weak but that their metabolism pattern depends on their chemical structure, monoterpenes being more extensively eliminated than sesquiterpenes. Nevertheless all this information has been provided by pharmacological studies in non-ruminant species (Kohlert et al., 2000), by studies on terpene elimination in milk (Viallon et al., 2000; Fernandez et al., 2003), or by studies in which terpene ingestion was not controlled (Cornu et al., 2001a,b; Priolo et al., 2004). Specific difficulties hinder the study of terpene fingerprints in ruminant meat products. First, the ruminant digestive tract, which initially functions as in monogastrics, undergoes considerable changes at weaning when the rumen comes into operation. Also, the animals follow different production systems associated with slaughter ages, varying from a few months to several years. Hence, diet changes generally occur at different stages (milk, growth, finishing), which are all likely to leave a mark and contribute to the terpene fingerprints of the tissues. So further information on terpene behaviour and dynamics in the tissues of ruminant species, including chemical structure of the tracers to be used, absorption/storage/elimination pathways, influence of the animal's characteristics (breed, sex, age, physiological stage) and influence of the tissue analysed, is required.

The aim of this study was to evaluate the potential of the essential oil-enrichment strategy to investigate terpene fingerprinting in muscle and adipose tissues of young bovines. The accumulation of a variety of monoterpenes, oxygen-containing monoterpene derivatives and sesquiterpenes in perirenal, subcutaneous and peritoneal fat and in rectus abdominis muscle was tested in controlled conditions.

\section{MATERIAL AND METHODS}

This trial was conducted on the INRA experimental farm at Marcenat (Cantal, France). 
Four male Montbeliard calves aged $52 \pm 5.1$ days were fed with natural cow's milk for their first month of life. From the second month, the calves were fed with commercial milk replacer (Univor Energie ${ }^{\circledR}$, Bongrain, France) supplemented (EO group: essential oil) or not (C: control group) with essential oils.

Essential oils kindly supplied by Pr. Lamaison and Pr. Carnat (Clermont-Ferrand Faculty of Pharmacy, Clermont-Ferrand) were mixed in the following volume proportions, by, \%: Achillea millefolium 27.5, Meum athamanticum 7.5, Pinus sylvestris 25.0, Vetiver zizanoides 35.0 and cinnamon oils 5 . The essential oil preparation was homogenized in commercial UHT cow's milk by gentle stirring in a water bath at $40^{\circ} \mathrm{C}$. Individual doses containing 5 and $20 \mu \mathrm{l}$ oil per $10 \mathrm{ml} \mathrm{milk}$ were stored at $-20^{\circ} \mathrm{C}$.

The calves were fed from buckets twice a day with reconstituted milk in amounts increasing from 5.5 to $8 \mathrm{l} / \mathrm{calf} /$ day during the four-month experiment. The essential oil doses were mixed with the commercial milk replacer reconstituted at $38-40^{\circ} \mathrm{C}$ just before administration. During the first week of the experiment, the EO calves received one dose of $5 \mu 1$ of essential oils at every meal (i.e. $10 \mu 1$ per day). During the second, third and fourth weeks, they received two, three and four $5 \mu \mathrm{l}$ doses, respectively, at each meal (i.e. from 20 to $40 \mu 1$ per day). From week 5 to slaughter they received one dose of $20 \mu \mathrm{l}$ at every meal ( $40 \mu \mathrm{l}$ per day). Cumulative samples of $50 \mathrm{ml}$ control and essential oil milks taken twice a day from both offered and refused milks were stored at $-20^{\circ} \mathrm{C}$.

Slaughter took place when the animals reached about $250 \mathrm{~kg}$ liveweight. The heaviest animal in each pair was slaughtered first, and the others 14 days later.

Samples of approximately $20 \mathrm{~g}$ fat taken at slaughter from the subcutaneous, peritoneal and perirenal adipose tissues, and $100 \mathrm{~g}$ rectus abdominis muscle were wrapped in aluminium foil, sealed in polyethylene bags with a vacuum packaging machine (Multivac, F77462 Lagny sur Marne), and stored at $-20^{\circ} \mathrm{C}$ until analysis.

Analyses

Lipid extraction. Muscle lipid was recovered as a supernatant after centrifuging about $80 \mathrm{~g}$ of roughly cut muscle at $75600 \mathrm{~g}$ for $2 \mathrm{~h}$ at $25^{\circ} \mathrm{C}$ in a Beckman Avanti J-301 centrifuge (Fullertown, CA 92834-3100, USA). Milk was defrosed at room temperature $\left(20^{\circ} \mathrm{C}\right)$ before the lipid was extracted by centrifuging about $88 \mathrm{ml}$ of milk, as described above.

Analysis of volatile compounds. Aliquots of $0.2 \mathrm{~g}$ extracted lipid or subsamples of $0.15 \mathrm{~g}$ adipose tissue taken from within each sample were deposited while frozen on 0.2 or $0.15 \mathrm{~g}$ glass wool in $40 \mathrm{ml}$ cylindrical glass extractors. Volatile compounds were extracted by dynamic headspace (DHS) and analysed by gas chromatography-mass spectrometry as previously described by Priolo et al. 
(2004) with a helium purge flow of $80 \mathrm{ml} / \mathrm{min}$ and a trap desorb temperature of $220^{\circ} \mathrm{C}$. Peak integrations were performed on the $\mathrm{m} / \mathrm{z} 93$ chromatogram for monoterpenoids and the $\mathrm{m} / \mathrm{z} 161$ chromatogram for sesquiterpenes, and are expressed as arbitrary area units.

Animal and tissue comparisons. Ranking of monoterpene ( $\mathrm{n}=14)$, oxygenated monoterpene $(\mathrm{n}=5)$ and sesquiterpene $(\mathrm{n}=18)$ areas were compared. Comparisons were performed using the Wilcoxon non-parametric rank test of the SAS software package (SAS, 1989). First, comparisons were performed on control vs essential oil animals separately for each tissue for monoterpenes, oxygenated monoterpenes and for sesquiterpenes, and second, two-by-two tissue comparisons were performed separately for each pair of calves for monoterpenoids and for sesquiterpenes.

\section{RESULTS}

Feed and essential oil intake, calf growth performance and slaughter results are reported in Table 1. Both EO calves had a higher liveweight gain than the controls, but not necessarily a higher milk intake.

Table 1. Calves' feed intake, growth performance and slaughter measurements

\begin{tabular}{|c|c|c|c|c|}
\hline & \multicolumn{2}{|c|}{ Control } & \multicolumn{2}{|c|}{ Essential oil } \\
\hline & $\mathrm{C} 1$ & $\mathrm{C} 2$ & EO1 & $\mathrm{EO} 2$ \\
\hline Reconstituted total milk intake, 1 & 1620 & 1787 & 1711 & 1948 \\
\hline Essential oil total intake, $\mu \mathrm{l}$ & 0 & 0 & 4435 & 5012 \\
\hline Time in experimental diets, days & 115 & 129 & 115 & 129 \\
\hline Slaughter age, days & 164 & 187 & 170 & 178 \\
\hline \multicolumn{5}{|l|}{ Liveweight, $\mathrm{kg}$} \\
\hline initial & 97 & 103 & 104 & 103 \\
\hline final & 260 & 260 & 273 & 296 \\
\hline Average daily liveweight gain, $\mathrm{kg}$ & 1.39 & 1.22 & 1.44 & 1.49 \\
\hline Final empty body weight, $\mathrm{kg}$ & 240 & 238 & 261 & 278 \\
\hline Carcass weight, $\mathrm{kg}$ & 148 & 139 & 157 & 167 \\
\hline Internal fat ${ }^{1}, \mathrm{~kg}$ & 6.59 & 9.68 & 9.84 & 10.70 \\
\hline Internal fat/final empty body weight, $\%$ & 2.74 & 4.06 & 3.76 & 3.85 \\
\hline Digestive tract weight/liveweight, \% & 9.6 & 10.1 & 11.0 & 8.0 \\
\hline
\end{tabular}

${ }^{1}$ sum of perirenal, peritoneal, mesenteric and pericardiac fat weights

The major terpenoid compounds found in the milk samples are given in Table 2. Fourteen monoterpenes, 2 oxygen-containing monoterpenes and 6 sesquiterpenes were found in the control milk while found to be enriched by one (junipene) to 63 times ( $\delta$-3-carene) in the EO milk. Three additional monoterpenes, five oxygen-containing monoterpenes and 23 sesquiterpenes were found in high 
Table 2. Terpenes and derivatives desorbed from reconstituted milk ${ }^{1}$

\begin{tabular}{|c|c|c|c|}
\hline & $\mathrm{LRI}^{2}$ & Essential oil milk & Control milk \\
\hline \multicolumn{4}{|l|}{ Monoterpenes } \\
\hline santolina triene & 908 & 7480 & 200 \\
\hline tricyclene & 931 & 33560 & 1397 \\
\hline$\alpha$-thujene & 933 & 39118 & \\
\hline$\alpha$-pinene & 944 & 806814 & 482496 \\
\hline camphene & 959 & 107442 & 9650 \\
\hline sabinene & 982 & 494257 & \\
\hline$\beta$-pinene & 989 & 610570 & 241889 \\
\hline$\beta$-myrcene & 993 & 243206 & 44659 \\
\hline$\alpha$-phellandrene & 1013 & 92410 & 2887 \\
\hline$\delta$-3-carene & 1020 & 195116 & 3092 \\
\hline$\alpha$-terpinene & 1025 & 19728 & 1221 \\
\hline$p$-cymene & 1032 & 6045 & 438 \\
\hline limonene & 1039 & 200562 & 43896 \\
\hline$\beta$-phellandrene $(+1,8$-cineole in EO $)$ & 1041 & 157473 & 34097 \\
\hline trans- $\beta$-ocimene & 1051 & 169474 & \\
\hline$\gamma$-terpinene & 1067 & 118594 & 2856 \\
\hline terpinolene & 1098 & 61006 & 13228 \\
\hline \multicolumn{4}{|l|}{ Monoterpene derivatives } \\
\hline$(1,8$-cineole $)$ & 1041 & + & \\
\hline linalool & 1103 & 12910 & \\
\hline camphor & 1163 & 7801 & \\
\hline lavandulol & 1172 & 13939 & \\
\hline terpinen-4-ol & 1192 & 18098 & 3199 \\
\hline$\alpha$-terpineol & 1204 & 28403 & 12802 \\
\hline $\begin{array}{l}\text { trans-sabinene hydrate acetate } \\
(+ \text { cuminal in EO) }\end{array}$ & 1258 & 3260 & \\
\hline bornyl acetate & 1302 & 12098 & \\
\hline \multicolumn{4}{|l|}{ Sesquiterpenes } \\
\hline$\alpha$-cubebene & 1371 & 4646 & \\
\hline$\alpha$-ylangene & 1398 & 8711 & 782 \\
\hline$\alpha$-copaene & 1403 & 19143 & 3669 \\
\hline$\alpha$-funebrene $+\beta$-bourbonene & 1415 & 11351 & \\
\hline unidentified sesquiterpene & 1431 & 3364 & \\
\hline junipene & 1447 & 20543 & 21707 \\
\hline$\beta$-ylangene & 1451 & 8034 & \\
\hline trans- $\beta$-caryophyllene & 1455 & 33353 & 7220 \\
\hline$\beta$-copaene & 1462 & 34796 & \\
\hline trans- $\beta$-farnesene + unidentified & 1472 & 18348 & \\
\hline trans-muurol-3,5-diene & 1482 & 4340 & \\
\hline$\alpha$-humulene & 1489 & 16145 & 1806 \\
\hline$\alpha$-acoradiene & 1498 & 27719 & \\
\hline vetispene $+\gamma$-muurolene & 1504 & 25291 & 2658 \\
\hline$\alpha$-amorphene & 1508 & 32446 & \\
\hline germacrene D & 1516 & 95944 & \\
\hline$\delta$-selinene & 1520 & 15824 & \\
\hline
\end{tabular}


Table 2. continued

\begin{tabular}{lccc}
\hline & $\mathrm{LRI}^{2}$ & Essential oil milk & Control milk \\
\hline$\beta$-vetispene $+\alpha$-muurolene & 1524 & 13299 & \\
$\gamma$-cadinene & 1547 & 25311 & \\
$\delta$-cadinene & 1551 & 47990 & \\
$\gamma$-vetivene & 1558 & 10152 & \\
trans-cadina-1(2),4-diene & 1560 & 10276 & \\
$\alpha$-cadinene & 1569 & 3408 & \\
unidentified $+\alpha$-calacorene & 1574 & 5646 & \\
unidentified sesquiterpene & 1581 & 3271 & \\
\hline
\end{tabular}

${ }^{1}$ arbitrary area units of the $\mathrm{m} / \mathrm{z}=93$ ion peaks for monoterpenes and derivatives and $\mathrm{m} / \mathrm{z}=161$ peaks for sesquiterpenes

2 linear retention indices

quantities in EO milk. Although it had a strong odour, this milk was well accepted by the calves.

Total monoterpenes, oxygen-containing derivatives and sesquiterpenes desorbed from the muscle lipid and from the four fatty tissues are presented in Figure 1. Monoterpenes and sesquiterpenes were more abundant in both EO than in the two $\mathrm{C}$ calves only for intermuscular, peritoneal and perirenal fatty tissues.

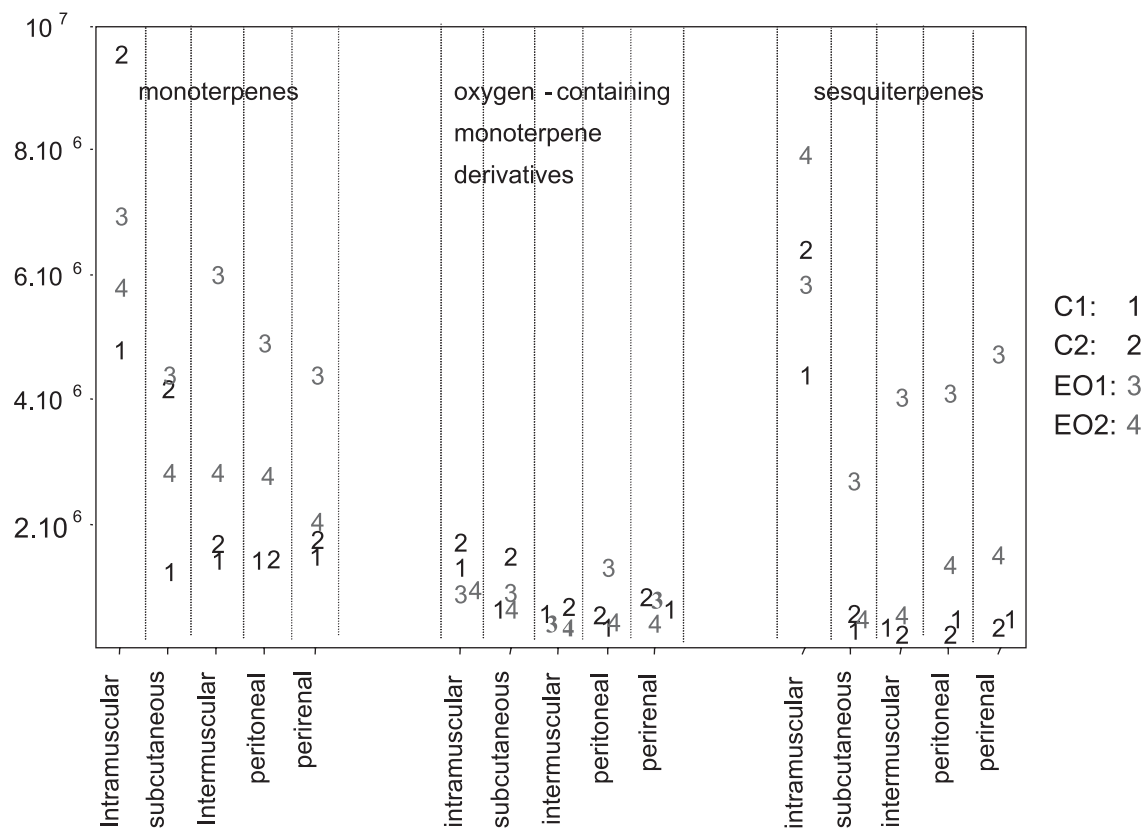

Figure 1. Monoterpenes, oxygen-containing derivatives and sesquiterpenes desorbed from intramuscular fat and from fatty tissues of the control $(\mathrm{C} 1$ and $\mathrm{C} 2)$ and essential oil (EO1 and $\mathrm{EO} 2)$ calves, expressed in arbitrary area units 
Tables 3 to 5 report the individual monoterpenes, oxygen-containing derivatives and sesquiterpenes detected in the fatty tissues and muscle lipids, together with the probabilities obtained from the rank tests. Terpenes with higher areas in the two EO than in the $\mathrm{C}$ animals are typed in bold.

Some of the terpenes found in the milk were not recovered in the adipose tissues: santolinatriene, tricyclene, $\alpha$-phellandrene, $\gamma$-terpinene, camphor, lavandulol, terpinen-4-ol, S1431, junipene, $\beta$-ylangene, $\alpha$-acoradiene, $\beta$-vetispene + $\alpha$-muurolene, S1574 + $\alpha$-calacorene, S1581. In contrast, some terpenes were detected in the $\mathrm{C}$ animals while they had not been found in the $\mathrm{C}$ milk.

Few monoterpenes and derivatives were found with higher areas in the two EO than in the two $\mathrm{C}$ animals. Peritoneal and intermuscular fatty tissues presented the highest scores (10 and 7 out of 17, respectively). The comparison of monoterpenoid contents, taking into account all individual areas, revealed no significant difference between the EO and $\mathrm{C}$ animals. Two-by-two comparisons of the fatty tissues did not reveal any significant difference in terms of monoterpenoid contents.

As shown in Table 5, relatively high scores were found for sesquiterpenes with higher areas in both EO animals: 16, 14, 9, 7 and 7 out of 19 in perirenal, peritoneal, intermuscular, subcutaneous and intramuscular samples, respectively. Comparison of sesquiterpene contents taking into account all individual areas (Table 5, $1^{\text {st }}$ comparison) showed that sesquiterpene contents were clearly higher in EO than $\mathrm{C}$ animals in all samples $(\mathrm{P}<0.0001$ for intermuscular, peritoneal and perirenal fats and 0.003 for subcutaneous fat) except intramuscular lipid $(\mathrm{P}=0.35)$. In the EO animals, sesquiterpene contents (Table $5,2^{\text {nd }}$ comparison) were higher in peritoneal $(\mathrm{P}=0.0124)$ and perirenal $(\mathrm{P}=0.0021)$ fat than in subcutaneous fat, and tended to be higher in perirenal than in intermuscular fat $(\mathrm{P}=0.0603)$.

Although 6 sesquiterpenes were found at higher levels in the two EO than in the two $\mathrm{C}$ intramuscular lipid samples, the corresponding ratios did not exceed 2.4 ( $\gamma$-cadinene). Not even one terpene was found to occur specifically in the EO muscle lipid. For many terpenes, these low values were attributable to their relatively high occurrence in the $\mathrm{C}$ animals. In fact, terpenes were higher in muscle lipid than in all fatty tissues, which only reflected the structural differences between samples. Whereas muscle lipids obtained by centrifugation formed a homogeneous oily phase, adipose tissues were solid, heterogeneous samples with varying proportions of connective tissue. Since volatile compound recovery by dynamic headspace (DHS) depends on the physicochemical properties of the matrix from which they have to be extracted, only structurally similar samples may be compared. 


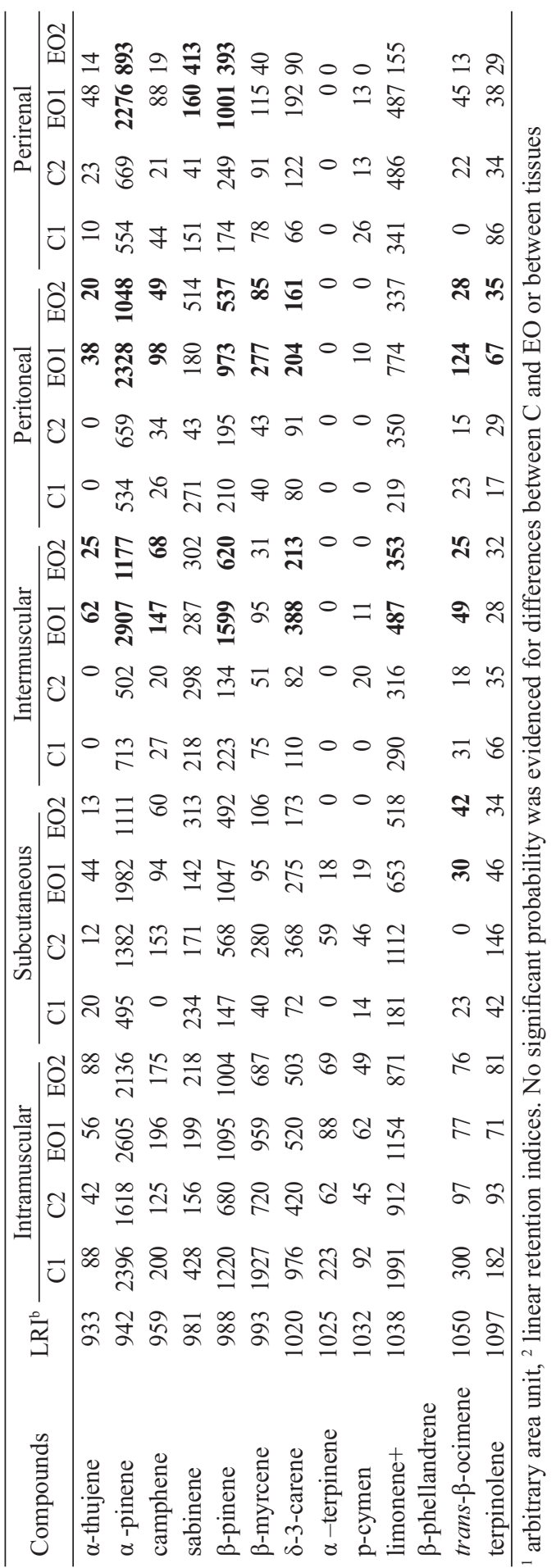

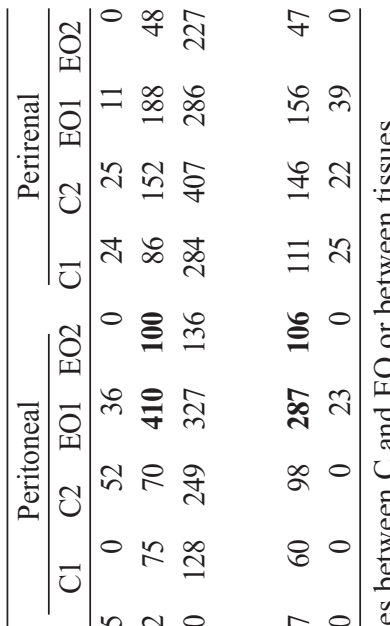

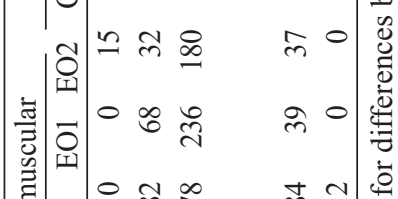

हี

उ 0 产

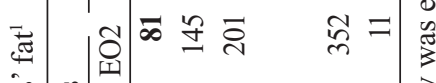

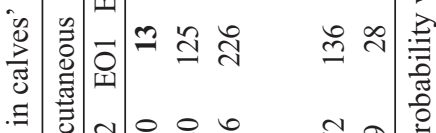

竞

:

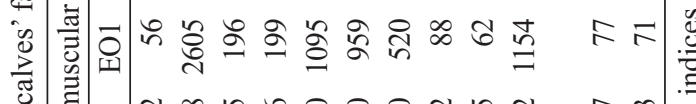

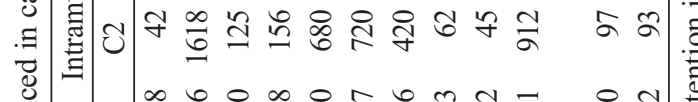

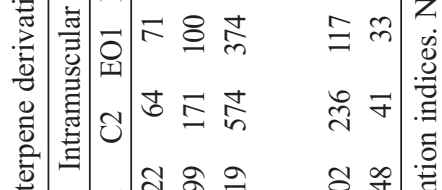

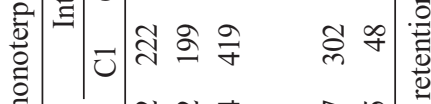

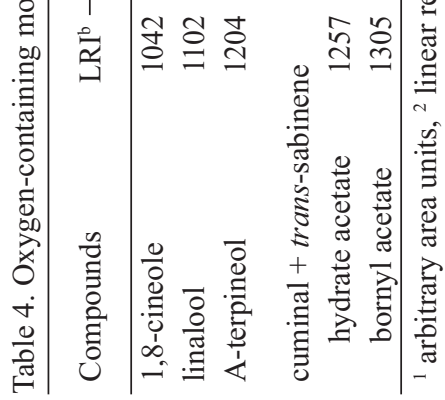




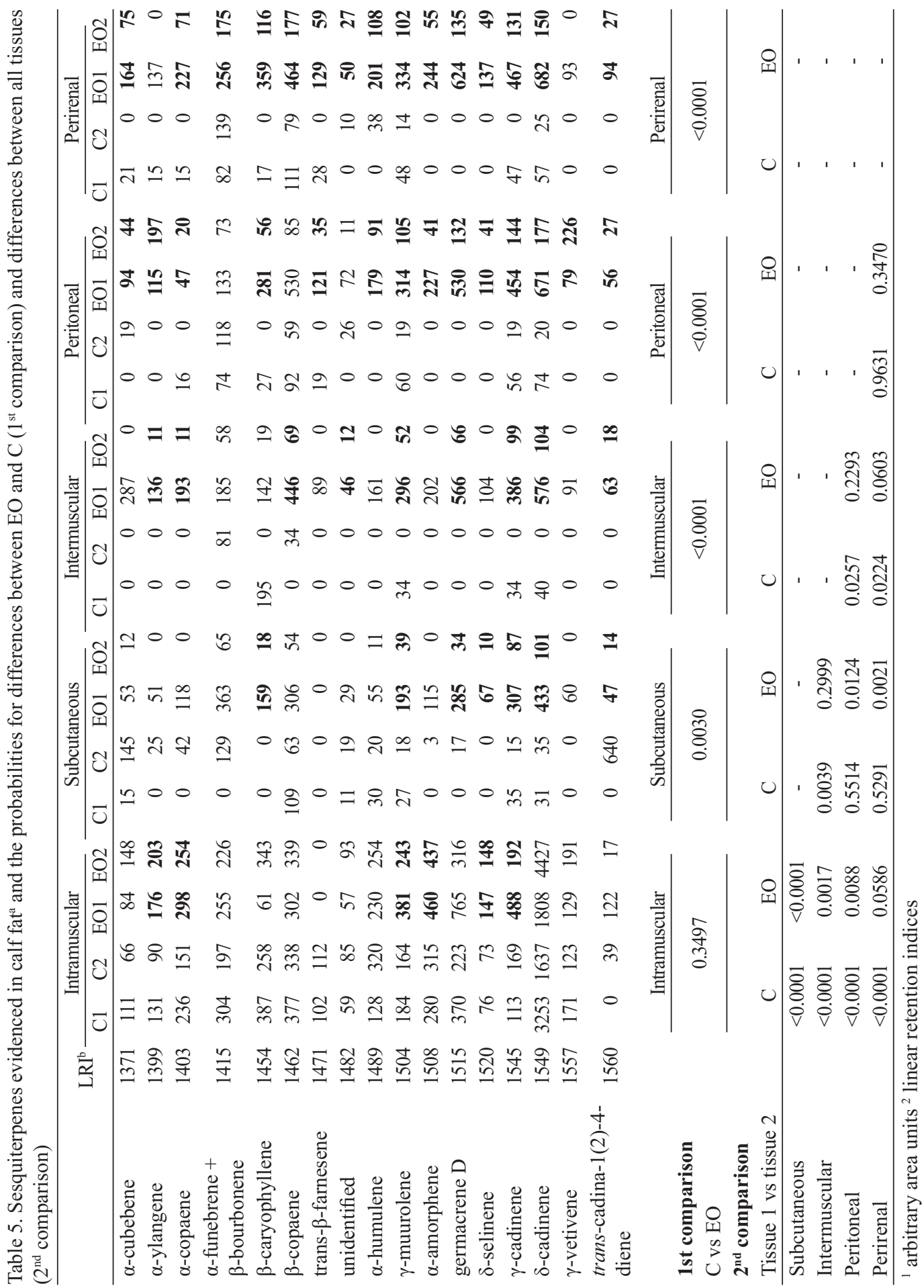




\section{DISCUSSION}

The low percentages in digestive tract relative to liveweights indicated a preruminant development stage for all four animals (Sautet, 1995).

Buchin and Salmon (2002) evaluated the total terpene content of milk from $4.610^{-3} \mathrm{ppm}$ in winter with cows fed on hay, up to $0.5 \mathrm{ppm}$ in summer with cows grazing highland pastures. This would correspond to an ingested amount of $8 \cdot 10^{-3} \mathrm{~g}$ for a calf receiving $151 \mathrm{milk} /$ day. The daily dose administered in the present experiment was 5-fold higher, in order to obtain stronger markings. In spite of this high dosing, feeding essential oils to the calves did not produce a drastic enrichment in their tissues, at least in terms of total terpenes. The excess terpene may have failed to be absorbed through the digestive tract, or may have been readily eliminated. This low accumulation is consistent with the high clearance values observed by Kohlert et al. (2000), who determined the average half-life of a variety of monoterpenes and oxygen-containing derivatives to be about one hour.

A variety of terpenes were found in the adipose tissues of the $C$ animals, some of which were not found in the corresponding milk: sabinene, linalool, trans-sabinene hydrate acetate, $\beta$-copaene and $\beta$-bourbonene. Since the C and EO animals were housed in the same room, these molecules may have been introduced from the air by absorption into the lungs (Shipe et al., 1962).

Terpene amounts found in a given tissue from the two $\mathrm{C}$ animals were generally very similar, whereas terpene amounts found in a given tissue from the two EO animals differed up to 18 -fold ( $\alpha$-copaene in intermuscular fat). On larger scales, high variation ranges of terpene contents were systematically observed when tracing grass feeding, vs low terpene diets in animal products (Cornu et al., 2002; Priolo et al., 2004). However, as shown in Figure 1, the relative position of the two EO animals was always the same, with the terpene content being higher in EO1 than in EO2. Interestingly, the total terpene dose ingested was lower for EO1 than for EO2 (Table 1). Individual variations between animals must therefore have other explanations than just the amount ingested.

The different terpene molecules behaved differently with regard to tissue accumulation. Globally, the terpenes accumulated the least were oxygen-containing monoterpene derivatives and the most, sesquiterpenes. Even at high enrichment levels in milk, monoterpene accumulation was low. This could be explained by lower absorption in the digestive tract and higher elimination of monoterpenoids from the animal's organism. Considering secretion in milk as a route of terpene elimination, these observations are consistent with the results obtained by Viallon et al. (2000) who found that monoterpene content in milk increased more rapidly than sesquiterpene content after feeding a terpene-rich diet. Besides, a number of studies on ovine fat (Priolo et al., 2004), on bovine fat and meat (Cornu et al., 2001b) and on dairy products (Fernandez et al., 2003) acknowledged sesquiterpenes as having a higher discriminating power than monoterpenes. 
According to Vernon (1986), fatty tissues mainly develop during the postnatal phase due to adipocyte hypertrophy, with the most precocious fatty tissue developing in perirenal tissue, followed by omental (including peritoneal), intermuscular and, lastly, subcutaneous tissue. Considering that terpenes would arrive in fatty tissues with the fatty acids, these differences in precocity of fatty tissue development could explain the between-tissue differences observed in the relatively young animals studied here. These between-tissue differences in terpene accumulation could imply differences in utility of the different tissues for tracing grass feeding. Along these lines, Priolo et al. (2004) have already hypothesized that differences in location of fat sampling (subcutaneous vs perirenal) could explain differences in skatole concentrations in different trials. In other studies, Priolo et al. (2002) and Serrano et al. (2006) found perirenal fat to be much more reliable than subcutaneous fat for discriminating grass feeding in young lambs and calves, respectively, using carotenoid absorption measurements.

\section{CONCLUSIONS}

Essential information emerges from these results concerning tissue marking by terpenes in young animals, which should be taken into account before considering studies on a larger scale. First, relatively high doses of essential oil are well accepted by calves. Even after a three-month treatment, this massive supply of terpenes did not induce very drastic enrichments in tissues, as observed in experiments where terpene-rich diets fed to cows led to terpene-rich milk. This suggests that elimination processes prevent terpenes from accumulating in the tissues in excessive amounts. At equivalent milk enrichment ratios, more occurrences of tissue marking were obtained for sesquiterpenes than for monoterpenes or their derivatives, making them better suited to differentiate animals based on their diet, as previously reported by other authors. Due to the extraction procedure, intramuscular lipid had a higher terpene concentration than adipose tissues, but was the medium least suited to differentiate $\mathrm{C}$ from EO animals. Finally, perirenal and peritoneal fat proved to be the most reactive tissues toward the increase in dietary terpenes. These preliminary results will provide a basis on which to design future experiments on terpene absorption, metabolism and storage/accumulation. Concerning traceability, it is most probable that only strongly contrasted feeding systems could be distinguished by using the terpene fingerprint in meat products.

\section{ACKNOWLEDGEMENTS}

The authors wish to thank Ph. Pradel and INRA-Marcenat staff and the team of the experimental slaughterhouse in Theix. 


\section{REFERENCES}

Buchin S., Salmon J.C., 2002. Estimation of the quantity of terpenes present in different types of milk. In: Proceedings of the $26^{\text {th }}$ IDF World Dairy Congress. Paris, pp. 24-27

Cornu A., Kondjoyan N., Begnaud F., Micol D., Renou J.P., Berdagué J.L., 2001a. Terpenes in meat: tracers of animal feed and geographical origin. In: VIII ${ }^{\text {èmes }}$ Rencontres Recherches Ruminants. Paris, p. 61

Cornu A., Kondjoyan N., Frencia J.P., Berdagué J.L., 2001b. Tracer l'alimentation des bovins. Déchiffrer le message des composés volatils des tissus adipeux. Viandes Prod. Carnés 22, 35-38

Cornu A., Kondjoyan N., Martin B., Ferlay A., Pradel P., Coulon J.B., Berdagué J.L., 2002. Toward the recognition of the main diets distributed to cows by means of terpene profiles in milk. In: IX $^{\text {èmes }}$ Rencontres Recherches Ruminants. Paris, p. 370

Favaro G., Magno F., Boaretto A., Bailoni L., Mantovani R., 2005, Traceability of Asiago mountain cheese: a rapid, low-cost analytical procedure for its identification based on solid-phase microextraction. J. Dairy Sci. 88, 3426-3434

Fernandez C., Astier C., Rock E., Coulon J.B., Berdagué, J.L., 2003. Characterisation of milk by analysis of its terpene fraction. Int. J. Food Sci. Technol. 38, 445-451

Kohlert C., van Rensen I., März R., Schindler G., Graefe E.U., Veit M., 2000. Bioavailability and pharmacokinetics of natural volatile terpenes in animals and humans. Planta Med. 66, 495-505

Larick D.K., Hedrick H.B., Bailey M.E., Williams J.E., Hancock D.L., Garner G.B., Morrow R.E., 1987. Flavor constituents of beef as influenced by forage and grain feeding. J. Food Sci. 52, 245-251

Martin B., Cornu A., Kondjoyan N., Ferlay A., Verdier-Metz I., Pradel P., Rock E., Chilliard Y., Coulon J.B., Berdagué J.L., 2005. Milk indicators for recognizing the types of forages eaten by dairy cows. In: J.F. Hocquette, S. Gigli (Editors). Indicators of Milk and Beef Quality. EAAP Publication No. 112, Wageningen, pp. 127-136

Prache S., Cornu A., Berdagué J.L., Priolo A., 2005. Traceability of animal feeding diet in the meat and milk of small ruminants. Small Ruminant Res. 59, 157-168

Priolo A., Cornu A., Prache S., Krogmann M., Kondjoyan N., Micol D., Berdagué J.L., 2004. Fat volatiles tracers of grass feeding in sheep. Meat Sci. 66, 475-481

Priolo A., Prache S., Micol D., Agabriel J., 2002. Reflectance spectrum of adipose tissue to trace grass feeding in sheep: Influence of measurement site and shrinkage time after slaughter. J. Anim. Sci. 80, 886-891

SAS/STAT ${ }^{\circledR}$, 1989. User's Guide Int., Version 6. $4^{\text {th }}$ Edition. Statistical Analysis Systems Institute Inc., Cary, NC

Sautet J., 1995. L'appareil digestif et ses adaptations. In: R. Jarrige, Y. Ruckebusch, C. Demarquilly, M.H. Farce, M. Journet (Editors). Nutrition des Ruminants Domestiques. INRA Editions. Paris, pp. 183-222

Serrano E., Prache S, Chauveau-Duriot B., Agabriel J., Micol D., 2006. Traceability of grass-feeding in young beef using carotenoid pigments in plasma and adipose tissue. Anim. Sci. 82, 909-918

Shipe W.F., Ledford R.A., Peterson R.D., Scanlan R.A., Geerken H.F., Dougherty R.W., Morgan M.E., 1962. Physiological mechanism involved in transmitting flavour and odors to milk. II. Transmission of some flavour components of silage. J. Dairy Sci. 45, 477-480

Vernon R.G., 1986. The growth and metabolism of adipocytes. In: P.J. Buttery, N.B. Haynes, D.B. Lindsay (Editors). Control and Manipulation of Animal Growth. Butterworths, London, pp. 67-83

Viallon C., Martin B., Verdier-Metz I., Pradel P., Garel J.P., Coulon J.B., Berdagué J.L., 2000. Transfer of monoterpenes and sesquiterpenes from forages into milk fat. Lait 80, 635-641

Young O.A., Berdagué J.L., Viallon C., Rousset-Akrim S., Theriez M., 1997. Fat-borne volatile and sheep meat odour. Meat Sci. 59, 183-200 